\title{
Restoring people and productivity to Puanui: challenges and opportunities in the restoration of an intensive rain-fed Hawaiian field system
}

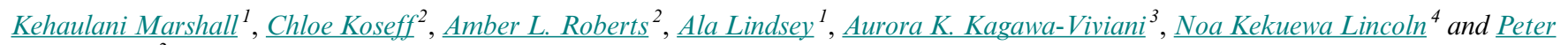
${\text { M. } \text { Vitousek }^{2}}^{2}$

\begin{abstract}
Prior to European contact, Hawaiian cultivators developed and sustained large rain-fed field systems based on sweet potato (Ipomoea batatas) and other crops. However, these intensive systems largely were abandoned in the 19th century, and there is little knowledge of how they functioned. Since 2008, we have worked to restore people and production to one such rain-fed field system at Puanui in leeward Kohala on the Island of Hawai'i using traditional knowledge, local knowledge, and experiments to understand how such systems functioned and to provide an educational and cultural resource to local communities. We encountered both climatic and biotic challenges to using traditional knowledge for restoring agricultural production. Climatically, there has been a recent drying trend and a severe 6-yr drought. Biotically, a wide range of weeds, pests, and diseases have been introduced to Hawaii since European contact. Experimental studies of cultivation practices demonstrated that rock mulching, a traditional practice, led to significantly greater yields of sweet potato than did alternative methods. More than 3000 students and community members have participated in the restoration effort and have contributed local and traditional knowledge in the process.
\end{abstract}

Key Words: biological invasion; cultivation practices; drought; Hawai'i; rain-fed agriculture; sweet potato; traditional agriculture

\section{INTRODUCTION}

Before European contact, intensively cultivated rain-fed (nonirrigated) agricultural systems produced most of the plantbased food that supported the Island of Hawai'i (Ladefoged et al. 2009). These rain-fed systems were local innovations that (within Polynesia) developed uniquely in the Hawaiian Archipelago; they were based on intensive cultivation of 'uala (Ipomoea batatas or sweet potato), and to a lesser extent dryland kalo (Colocasia esculenta or taro), uhi (Dioscorea spp. or yam), 'ulu (Artocarpus altilis or breadfruit), mai'a (Musa spp. or banana/ plantain), and kō (Saccharum officinarum or sugarcane), among other crops. Rain-fed systems largely were abandoned by the mid-1800s because of depopulation and attendant social disruption from introduced disease, and the depredations of introduced ungulates; today, the remains of these systems are found mostly on private property with limited public access, and in many regions, even the memory of their existence has faded. Another widely important Hawaiian cropping system, lo'i kalo (irrigated taro pondfields), was the dominant production system on geologically older islands in the archipelago; this system persisted despite the devastation of introduced disease and the disruptions and dislocations of subsequent colonization. Not only did these production systems differ, but they also embodied distinctive social-environmental systems (Walker et al. 2004, Ostrom 2009) that differed in multiple social and cultural dimensions (Kirch 1994, 2010).

Beginning in 2008, we have worked to restore agricultural production and educational opportunities to a portion of the rain-fed Leeward Kohala Field System (LKFS) in the ahupua'a (traditional Hawaiian land division) of Puanui. The LKFS was a $>60 \mathrm{~km}^{2}$ field system on the leeward slope of Kohala Volcano (Ladefoged et al. 2011); it was one of several large rain-fed systems on the Island of Hawai'i that for about two centuries before
European contact supported what was likely a larger population than the nearly 200,000 people who now reside on the island (although precontact human population estimates are uncertain and controversial in Hawai'i, as elsewhere; Stannard 1989, Dye and Komori 1992, Kirch 2007). With support from the landowner and the lessee, we began planting Hawaiian crops within three fenced gardens within the LKFS in Puanui, initially as a Stanford University research project with community participants, and more recently as the community-based nonprofit Ulu Mau Puanui, managing the work with participants from Stanford University.

While we are fascinated by the social-environmental system that sustained and was sustained by rain-fed field systems, our focus here is on agricultural production. Accordingly, we contextualize this work within the domain of traditional knowledge and practices (Berkes et al. 2000, Durie 2005). We follow Durie (2005) in seeking not to integrate traditional knowledge and practice with "western scientific" approaches, but rather to find ways that the specificity and depth in time of traditional knowledge can communicate effectively with the reproducibility and generalizability of science and thereby inform and enrich each other. We believe that undestanding of this extinct agricultural system must emerge from a diversity of knowledge sources, so we use scientific approaches to ask questions about how the field system worked, and complement this approach with community interest in Hawaiian cultural revitalization. Here, we describe the structure of the restoration work, building on an earlier publication (Kagawa and Vitousek 2012); we evaluate ways that modern changes in biophysical conditions (climate and biota) have influenced restoration; we document research on agricultural practices and the implications of those practices; and we describe the educational and outreach components of work at Puanui.

${ }^{1}$ Ulu Mau Puanui, ${ }^{2}$ Stanford University, ${ }^{3}$ Department of Geography, University of Hawai'i-Mānoa, ${ }^{4}$ Department of Tropical Plant and Soil Sciences, University of Hawai'i-Mānoa 
Fig. 1. Map of North Kohala, Hawai'i. The map shows the ahupua'a of Puanui (wide black line), the 150,000 year old Hawi Volcanic Formation (medium grey), the 400,000 year old Pololu Volcanic Formation (light grey), 100-m elevation contours (thin black lines), and rainfall isohyets (white lines). Figure contributed by T.N. Ladefoged.

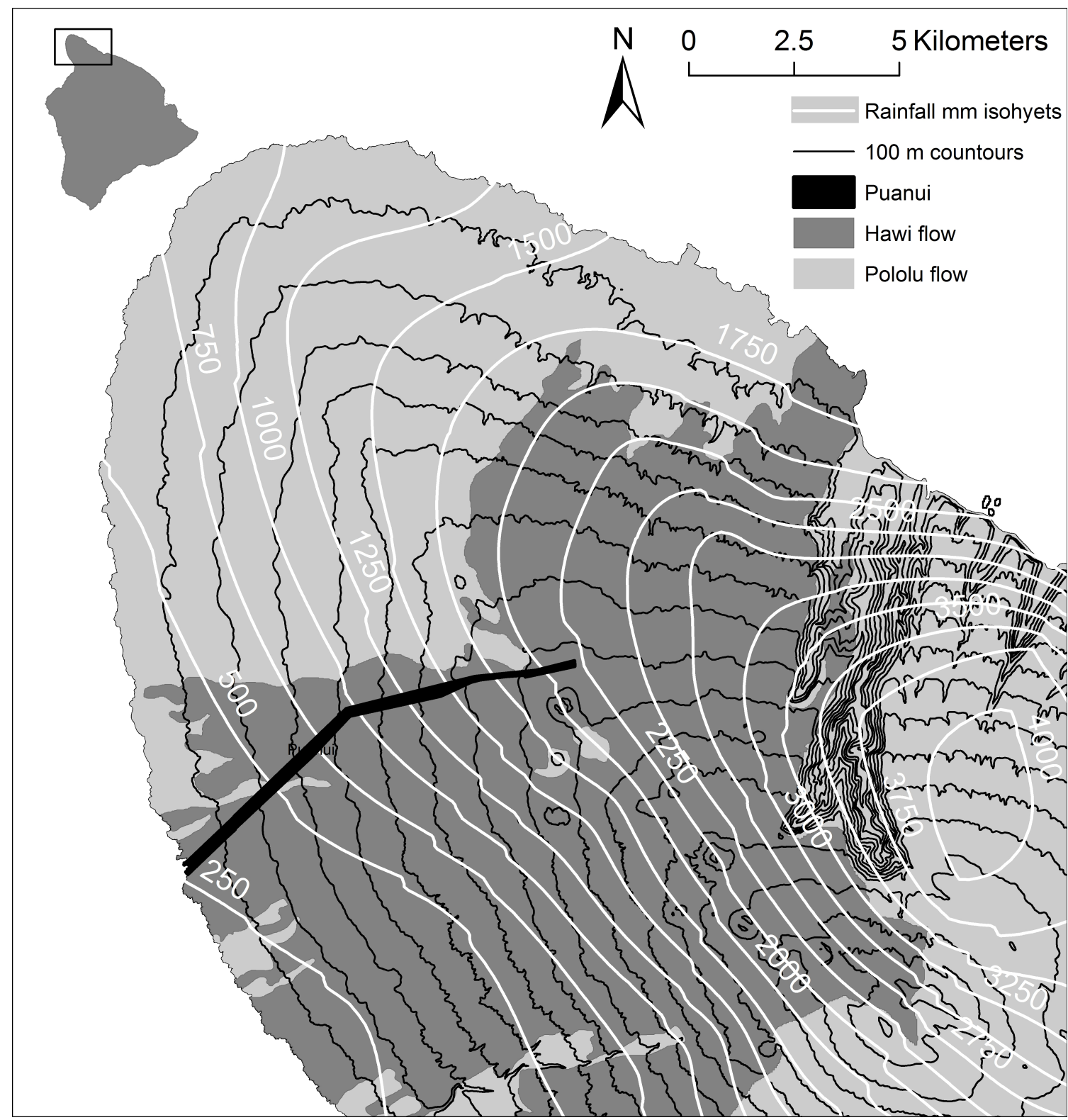

\section{STUDY SITE}

The ahupua'a of Puanui extends from the northwest ridge of Kohala Volcano at $\sim 845 \mathrm{~m}$ elevation down the leeward southwestern slope to the sea (Fig. 1). Kohala supports a remarkable precipitation gradient along which annual rainfall declines from approximately $4500 \mathrm{~mm} / \mathrm{yr}$ windward of the summit to $<250 \mathrm{~mm} / \mathrm{yr}$ at the coast only $17 \mathrm{~km}$ away (Giambelluca et al. 2013). The relationships among climate and soils (Chadwick et al. 2003, Vitousek and Chadwick 2013) and the link between soils and the presence of intensive rainfed agriculture (Vitousek et al. 2004, Vitousek et al. 2014) are well documented on leeward Kohala. Important environmental features include a zone of very high soil fertility supported by ongoing mineral weathering and past biological uplift that underlies the rain-fed agricultural system (with moderately fertile soils but arid conditions in drier regions and acid infertile soils in wetter regions; Vitousek and Chadwick 2013), patterns of year-round rainfall on the windward slope and a winter rainfall peak on the leeward slope, and frequent high-velocity trade winds that blow over the summit ridge down toward the sea.

The ahupua' $a$ of Puanui is $14 \mathrm{~km}$ long but only $100 \mathrm{~m}$ wide across much of its range. It contains no permanent surface streams, and its network of ephemeral drainage is oriented obliquely to the 
boundaries of the ahириа'a. Prior to Polynesian discovery of Hawai'i, most of leeward Kohala was forested from its upper reaches to the coast (Chadwick et al. 2007). Following Polynesian discovery but before European contact, most of the ahupua'a below $\sim 750 \mathrm{~m}$ elevation was transformed by Hawaiian cultural uses that included: intensive agriculture and many house sites from $\sim 470$ to $730 \mathrm{~m}$ elevation, an area that was burned to support pili grass (Heteropogon contortus) production for use as thatching material from $\sim 470 \mathrm{~m}$ to near the coast, and a zone of habitation at the coast (Field et al. 2011a,b).

Within Puanui, we established three fenced experimental gardens, here termed māla. Fencing is essential because cattle grazing is ongoing, feral pigs are present in the region, and both cattle and pigs are voracious consumers of Hawaiian food crops. One of the $m \bar{a} l a$ is located near the upper wetter margin of the traditional field system at $\sim 730 \mathrm{~m}$ elevation, one is located near the lower drier margin at $490 \mathrm{~m}$, and one is located at $690 \mathrm{~m}$ (Kagawa and Vitousek 2012). The upper and lower mā $l a$ are approximately 40 x $40 \mathrm{~m}$, whereas the middle one is approximately $65 \times 65 \mathrm{~m}$ (to support community-based projects and experiments). Five online weather stations were established in Puanui: one in each $m \bar{a} l a$, one near the upper margin of the ahupua'a, and one near the coast.

\section{CHALLENGES TO RESTORING TRADITIONAL AGRICULTURE}

Two important difficulties in implementing traditional ecological knowledge in practice occur when there is an extended break in the continuity of practice and when the biophysical conditions under which traditional knowledge developed change (Higgs et al. 2014). Here, we faced both difficulties. First, we lack a working reference system to serve as a model for restoration and research efforts; the field system has not been farmed as a system for well over a century. We can, however, draw upon archaeology, ethnographic and ethnohistorical accounts, and living culture to develop hypotheses for how the field system appeared and how it was managed. This process is iterative and interactive, as in descriptions of learning in adaptive comanagement settings (Armitage et al. 2008, Diver and Higgins 2014). At Puanui, our understanding of local archaeology and ethnohistory influences the design of field experiments. Outreach activities share research findings in ways that enable exchange of local and traditional knowledge. The resulting insights in turn shape the interpretation of field observations and influence the design of future activities and experiments.

Biophysical changes are particularly challenging when there has been an extended break in practice such that traditional knowledge has not evolved with changing conditions. We encountered two major classes of biophysical challenges to restoring agricultural production: climatic and biotic. Climatic challenges reflected an intense drought and recent multiyear drying in the area (Frazier and Giambelluca 2017), whereas the biotic challenges reflected the postcontact introduction of new weeds, pests, and plant diseases.

\section{Climate}

We evaluated both long-term average rainfall and the influence of an extended drought that encompassed the first several years of restoration. Earlier work demonstrated that the distribution of the LKFS was set by climate and soil fertility (Vitousek et al. 2004), with the lower margin bounded by low rainfall and the upper margin bounded by a threshold in soil fertility that reflects the long-term influence of climate on weathering and leaching of soils (Chadwick et al. 2003, Vitousek et al. 2004, Vitousek and Chadwick 2013). Use of an earlier rainfall atlas of Hawaii (Giambelluca et al. 1986) yielded mean annual rainfall levels of 750 and $1700 \mathrm{~mm} / \mathrm{yr}$ for the lower and upper bounds for intensive agriculture in the area encompassing Puanui. However, the latest state-wide rainfall atlas based on a more recent time interval (1978-2007) yielded higher rainfall in leeward Kohala and suggested boundaries near 1000 and $1900 \mathrm{~mm} / \mathrm{yr}$ (Giambelluca et al. 2013). The actual values are important because they represent a fundamental input to a model of the archipelago-wide distribution of rain-fed field systems (Ladefoged et al. 2009).

We sought to determine the actual rainfall bounds of agricultural intensification in Puanui. This effort was made possible by the fact that neighboring ranches just to the north and south of Puanui have maintained rainfall records for the past 20-25 years. One ranch (Ponoholo Ranch) has four stations that span an elevation and rainfall range from above to well below the boundaries of the LKFS and that provide complete rainfall records from 1990 to the present. The other ranch (Parker Ranch) has one station located near the upper margin of the LKFS. We also evaluated a longer term rainfall record from Kahua Ranch, which is an official station located just upslope from the LKFS, 4 $\mathrm{km}$ south of Puanui.

We calculated mean annual rainfall at each of the ranch stations for the interval of 1990-2007 (1993-2007 for Parker Ranch) before a recent multiyear drought. We compared these means with calculated values from the recent rainfall atlas (Giambelluca et al. 2013). Observations from the ranches were systematically lower than the mapped values from the atlas (Table 1). We correlated the ranch records for monthly rainfall with monthly rainfall for shorter term climate records from our stations in Puanui and used these correlations to calculate that the rainfall values associated with the lower and upper bounds of the LKFS in Puanui to be $\sim 600$ and $\sim 1200 \mathrm{~mm} / \mathrm{yr}$, respectively.

Although long-term average rainfall is useful in establishing a context, the real climatic challenge to restoration has been a substantial recent decline in rainfall (Frazier and Giambelluca 2017), exacerbated by a multiyear drought that began in 2008 . Every year from 2008 (when we initiated the study) to $2013 \mathrm{had}$ rainfall substantially below average, whereas 2014 and 2015 were wetter (Fig. 2). The longer term record from Kahua Ranch (Fig. 3 ) demonstrates that since 1931, there has been no 5-year period as dry as the 6 years from 2008-2013, and no equivalently dry 4year period since the early $1930 \mathrm{~s}$.

This 6-year dry period represented a significant challenge to restoration. Calculated rainfall values at our upper (wettest) $m a \bar{l} l a$ in Puanui averaged $~ 700 \mathrm{~mm} / \mathrm{yr}$ for 2008-2013, and those at the lowest $m a \bar{l} l a$ averaged $<350 \mathrm{~mm} / \mathrm{yr}$ (vs. 1200 and $600 \mathrm{~mm} / \mathrm{yr}$, respectively for longer term rainfall bounds). Annual average rainfall levels that were marginal for intensive cultivation occurred near the upper, wetter edge from 2008-2013. We do not know if these lower rainfall values represent a new normal. Rainfall is declining overall in leeward Hawaii (Fig. 2; Frazier and Giambelluca 2017), and climate change projections (Timm and Diaz 2009) suggest that a warmer world will bring substantial leeward drying to Hawai'i; however, the 2008-2013 observations represent an even more extreme scenario than the projections. 
Table 1. Rainfall amounts measured at stations near Puanui, Hawai'i. Rainfall was measured at private stations to the south (Ponoholo Ranch) and north (Parker Ranch, beginning in 1993) of Puanui. Neither Ponoholo nor Parker stations were used in the mapped rainfall; another nearby station, Kahua Ranch, was used. A 6-yr drought occurred in 2008-2013. Calendar years 2014-2015 include only 2014 for Kahua Ranch. Mapped rainfall for the Kahua station is substantially in excess of the measured rainfall there, and this difference appears to apply to all of these stations.

\begin{tabular}{lccccc}
\hline \hline & $\begin{array}{c}\text { Mapped } \\
\text { rainfall } \\
(\mathrm{mm} / \mathrm{yr})^{\dagger}\end{array}$ & \multicolumn{5}{c}{ Measured rainfall (mm/yr) } \\
\cline { 3 - 6 } Site & $1978-2007$ & $\begin{array}{c}1990- \\
2007\end{array}$ & $\begin{array}{c}2008- \\
2013\end{array}$ & $\begin{array}{c}2014- \\
2015\end{array}$ & $\begin{array}{c}1978- \\
2007\end{array}$ \\
\hline $\begin{array}{l}\text { Ponoholo } \\
\text { Ranch 1 }\end{array}$ & 2502 & 2291 & 1499 & 2330 & \\
$\begin{array}{l}\text { Ponoholo } \\
\text { Ranch 2 }\end{array}$ & 1770 & 1401 & 881 & 1604 & \\
$\begin{array}{l}\text { Ponoholo } \\
\text { Ranch 3 }\end{array}$ & 1047 & 681 & 355 & 541 & \\
$\begin{array}{l}\text { Ponoholo } \\
\text { Ranch 4 }\end{array}$ & 450 & 274 & 190 & 266 & \\
$\begin{array}{l}\text { Parker Ranch } \\
\text { Kahua Ranch }\end{array}$ & 1549 & 1215 & 723 & 1342 & \\
\hline
\end{tabular}

Source: Giambelluca et al. (2013).

Fig. 2. Rainfall, measured at stations near Puanui from 1990 2013. Plotted values are 3-yr running means; values next to station names are mapped values for average rainfall from the Rainfall Atlas of Hawaii (Giambelluca et al. 2013).

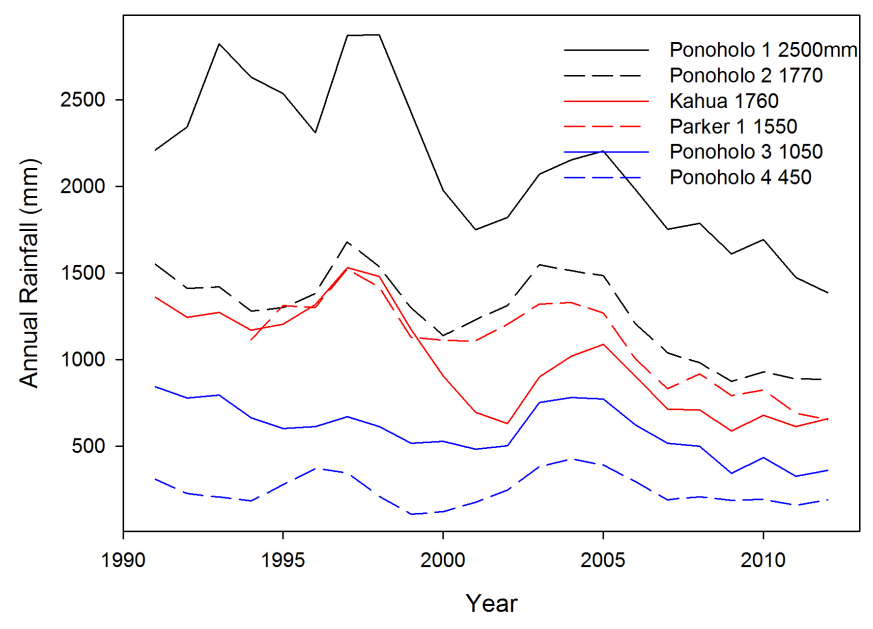

\section{Biota}

Species introductions pose multiple, well-recognized threats to native species and ecosystems (Mooney and Drake 1986, Vitousek et al. 1997), especially on oceanic islands. Analyses of introduced species in agriculture are more complex. The main traditional staple crops were brought to Hawai'i by Polynesians and are referred to as canoe plants, reflecting their mode of arrival.
Fig. 3. Rainfall measured at Kahua Ranch Headquarters, 4 km south of Puanui, since the early 1930s. Values are 3-yr running means. Mapped rainfall for the location is $1760 \mathrm{~mm} / \mathrm{yr}$ for the period of 1978-2007; measured rainfall for that period is 1273 $\mathrm{mm} / \mathrm{yr}$ (Giambelluca et al. 2013).

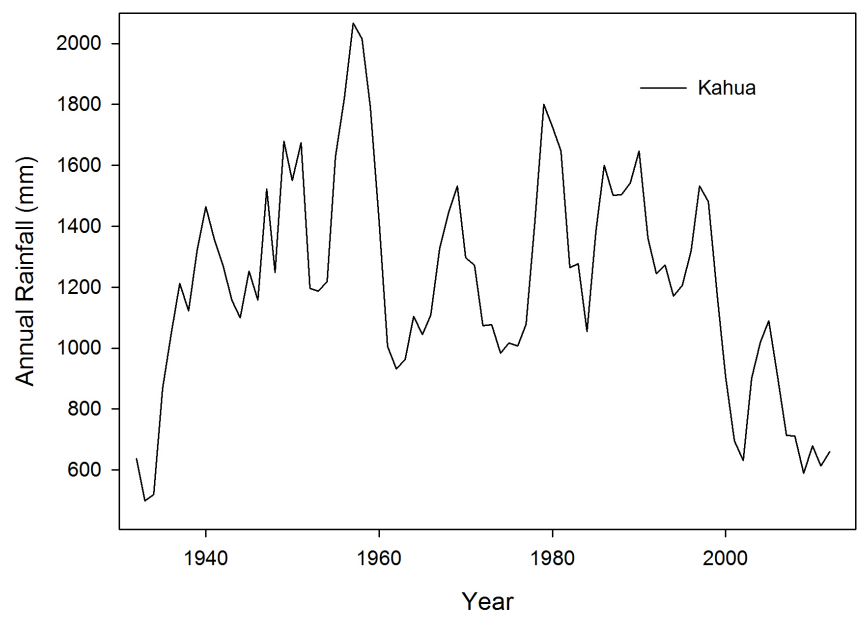

However, precontact Hawaiian cultivators had a limited suite of native weeds and pests with which to contend. The postcontact transport of many of the world's weeds, pests, and diseases to Hawai'i poses serious challenges for the restoration of traditional rain-fed Hawaiian cropping systems.

Puanui has been managed for cattle grazing for $>100$ years, and multiple pasture grasses and associated species now dominate the area. The current dominant grass over the wetter portion of the landscape, kikuyu grass (Pennisetum clandestinum), forms mats with a dense root system. This grass is extremely effective at regenerating from root fragments and at sending runners into areas from which it has been cleared. It is overwhelmingly the most challenging weed in the cultivated areas, and Hawaiian cultivators did not have to deal with it or anything like it. Other significant contemporary weeds include perennial soybean (Neonotonia wightii) and Madagascar fireweed (Senecio madagascariensis). In contrast, ethnographic sources suggest that weeds in traditional systems were few and relatively easily managed. One source reports, "In the olden days when the only grass was the kukaepua'a [Digitaria spp., most often described as indigenous, but with dissenting opinions] ... no other weeds grew with the kukaepua'a grass," (Handy and Handy 1972).

In addition to weeds, numerous insects and diseases now affect sweet potato in Hawaii and elsewhere (Valenzuela et al. 1994, Ames et al. 1997), to the point that modern growers do not grow two crops in succession on the same site. The most significant insect pests in Hawaii include the introduced sweet potato weevil (Cylas formicarius) and sweet potato stem borer (Omphisa anastomosalis). Introduced pests of sweet potato have been present in Hawaii for $>100$ years (Fullaway 1911). Prior to the arrival of these pests, Hawaiian cultivators faced infrequent outbreaks of 'enuhelpe'elua (native hawkmoth caterpillars). Later accounts refer to kakala (cutworms) and $m \bar{u}$ (weevils) as 
challenging cultivators in some areas. One source speaks to agriculture "being subject to caterpillar epidemics, when the creatures swarm over everything, eating grass, the foliage of the taro and potatoes, and even stripping the trees" (Handy and Handy 1972), but these epidemics appear to have been rare occurrences.

Finally, introduced animals have disrupted planting substantially in Puanui. Although we excluded ungulates using fences, game birds, especially ring-neck pheasant (Phasianus colchicus) and turkey (Meleagris gallopavo), consume sweet potato tubers and can essentially eliminate useful harvests. Field mice (Mus musculus) are abundant, particularly in drier regions, and will eat young leaves and shoots of many of the sprouting plants, particularly $k \overline{1}$ (Cordyline fruticosa) and 'uala. We observed seasonal population booms and migrations of mice reminiscent of the accounts of rats in ancient times. Rats were said to be the worst pests of 'uala during the wet season (Kepelino 1932, Handy 1940, Handy and Handy 1972).

\section{EXPERIMENTS WITH CULTIVATION PRACTICES}

Ethnographic descriptions of rain-fed field systems in Hawaii (Kelly 1983, 1989) and the 'ôlelo no'eau (literally, wise story, perhaps most appropriately aphorism) I 'ike 'ia no o Kohala i $\mathrm{ka}$ pae $k \bar{o}$ (One can recognize Kohala by her rows of sugarcane; Pukui 1983 ) are consistent in describing $k \bar{o}$ (sugarcane, introduced by Polynesian voyagers) as being in widespread cultivation and use within these systems. Accordingly, we sought to build on this traditional practice by establishing a production system using $k \overline{0}$ planted in rows along the remnant Hawaiian field walls, with 'uala (sweet potato) in the spaces between walls. In addition, several other Polynesian introductions and native plants have been planted into the mâla. Of these, kalo (taro) has failed to yield useful tubers several times (perhaps because of the drought), but $k \overline{1}$ (Cordyline fruticosa) and mai' a (banana or plantain; Musa spp.) survived in the upper māla, and ipu (Lagenaria siceraria) produced large gourds in the middle mâla. Planted individuals of the native leguminous trees wiliwili (Erythrina sandwichensis) and koai'a (Acacia koaia) also grew in the middle māla.

We planted several traditional and modern varieties of $k \bar{o}$ on the field walls within the fenced gardens of the middle $m \bar{a} l a$ and in rows within the upper māla (where the original field walls were obscure). Originally, $k \overline{\mathrm{o}}$ was intended to function as a windbreak and a source of mulch for 'uala; however, we observed that highly effective windbreaks dried out and killed plants to their leeward. We found ethnohistorical reports from traditional cultivators that demonstrated that they harvested blades of $k \overline{0}$ at the first sign of senescence and so maintained sparse and spindly rows. We also measured nutrient content and decomposition rates of blades of $k \bar{o}$ harvested early and late in senescence and found more rapid nutrient supply when leaves were harvested early (Lincoln et al. 2014). We now believe that traditional cultivators balanced the ability of $k \bar{o}$ to serve as a windbreak with its function as a mist trap (accumulating cloudwater and mist) and, to that end, maintained sparse and spindly rows of $k \bar{o}$ that we now seek to duplicate. Moreover, measurements in the Kona district of the island demonstrated that decomposing $k \bar{o}$ litter can represent an important source of biological nitrogen fixation (Lincoln and Vitousek 2016).

'Uala was planted in raised beds in all three māla beginning in 2009; multiple varieties were grown, but eventually, we settled on the presumed Hawaiian variety 'Lanikeha' for experiments, a variety that was preserved within the Kohala community and found through community outreach and engagement. Results from the first few years of cultivation are reported in Kagawa and Vitousek (2012); briefly, before 2012, we obtained consistent yields in the upper two māla but only one successful crop in the lowest māla. These measurements provided information on production potential. To learn more about traditional agricultural practices, we initiated an experiment to evaluate mounding and mulching practices for 'uala cropping.

Ethnographic observations describe 'uala as being planted using a variety of methods, often in mounds created with 'o' $\bar{o}$ (digging sticks) and mulched with rocks and plant material (James 1857, Handy 1940, Handy and Handy 1972, Kamakau 1976). In Puanui, residual rock planting mounds occur between the field walls throughout the LKFS and more abundantly in the dry portions. Accordingly, we established an experiment in which multiple mounds of approximately $1 \mathrm{~m}^{2}$ were established in all three mā $l a$ and divided into four treatment levels: no mulching, mulched with rocks, mulched with plant litter, and mulched with rocks and plant litter. All mounds were started with the soil thoroughly loosened to a depth of $\sim 30 \mathrm{~cm}$. Sixteen 'uala cuttings were then planted on each mound, and mulching treatments were imposed at random. There were four mounds of each treatment in the middle māla and one of each treatment in the smaller upper and lower $m \bar{a} l a$. Mounds were established and 'uala planted in late July 2014. Those mounds were harvested and another set established in late November 2014 and again in late March 2015. The final set of mounds was harvested in late July 2015.

Harvested weights of 'uala tubers are summarized in Table 2. In all three seasons, rock proved to be the most effective mulch. In each case, the rock and plant litter combination was second best of the four treatments. ANOVA showed that the effect of mulching treatment in the middle māla (where there was sufficient replication for statistical analysis) was significant in the winter planting $(P<0.001)$ and marginally so in the spring $(P<0.1)$; it was not statistically significant in the summer planting $(P>0.05)$. We suggest that rock mulch succeeded because rocks suppress surface evaporation and weeds while allowing rainwater to percolate into the soil, and (especially in the last interval) because rocks prevented pheasants and turkeys from consuming potatoes.

Across seasons, the winter trials produced the highest yields, likely because of greater rainfall. The rock-mulched plots of the middle $m \bar{a} l a$ had an average yield of $2.2 \mathrm{~kg} /$ mound in the winter compared to $1 \mathrm{~kg} /$ mound in both summer and spring. The greater yield in winter was marginally significant $(P=0.056)$.

These results agree with archaeological and ethnohistorical evidence that Hawaiians used rock mulch extensively. Hawaiians may also have used vegetation mulch more successfully than we did because cultivators were always on site and able to remove mulch during rain and replace it afterwards; this is a welldocumented practice in the Kona dryland field system (Handy and Handy 1972).

\section{PUANUI AS AN EDUCATIONAL RESOURCE}

Ulu Mau Puanui provides access to the land for schools and for community members to work on the rain-fed agricultural system and to contribute to the process of discovery. Programs include both one-time visits to Puanui by community groups or distant 
Table 2. Yields (kg/mound) of 'uala (Ipomoea batatas or sweet potato) in a mulching and mounding experiment. Mounds were harvested when the next set of mounds were established, with the final set harvested in July 2015 . The water content of sweet potatoes is $80 \%$ (Kagawa and Vitousek 2012), and mounds were $\sim 1 \mathrm{~m}^{2}$. For the middle $m \bar{a} l a$, values are means of four mounds, with standard deviations in parentheses.

\begin{tabular}{|c|c|c|c|c|c|}
\hline \multirow[b]{2}{*}{ Location } & \multirow[b]{2}{*}{ Planting date } & \multicolumn{4}{|c|}{ Treatment } \\
\hline & & No mulch & Rock & Organic & Rock and organic \\
\hline \multirow[t]{3}{*}{ Upper māla } & July 2014 & 0 & 1.6 & 0 & 0.7 \\
\hline & November 2014 & 0.9 & 1.3 & 0.9 & 1.5 \\
\hline & March 2015 & 0.4 & 1.0 & 0.8 & 0.9 \\
\hline \multirow[t]{3}{*}{ Middle $m a \bar{l} l a$} & July 2014 & $0.4(0.5)$ & $1.0(0.6)$ & $0.3(0.3)$ & $0.5(0.3)$ \\
\hline & November 2014 & $0.6(0.5)$ & $2.2(0.4)$ & $1.3(0.3)$ & $1.5(0.4)$ \\
\hline & March 2015 & $0.05(0.01)$ & $1.0(1.0)$ & $0.05(0.01)$ & $0.6(0.3)$ \\
\hline \multirow[t]{3}{*}{ Lower māla } & July 2014 & 0 & 0 & 0 & 0 \\
\hline & November 2014 & 0.9 & 0.5 & 1.5 & 0 \\
\hline & March 2015 & 0 & 0 & 0 & 0 \\
\hline
\end{tabular}

schools and repeated visits to Puanui by local families and schools in which visitors establish and evaluate their own agricultural measurements and experiments. From 2011-2015, a total of 3169 individuals participated in visits to Puanui that were organized by Ulu Mau Puanui. Of these visitors, 58\% were from the Island of Hawai'i and so were connecting to their own land to some extent. Of all visitors, $38 \%$ were adults, $14 \%$ were college students, $9 \%$ were high school students, $8 \%$ were middle school students, and $29 \%$ were elementary school students.

All programs encourage participatory learning to "wonder how..." and come up with solutions ("let's try..."), to articulate why something should work, and (in the case of repeat visitors) to articulate why it did or did not work and defend that understanding with measurements. The intent of this inquirybased framework is to engage participants' creativity while practicing cultural values, including observation, having a relationship to the land and other learners, respect, and kuleana (responsibility and privilege). All visitors to Puanui should experience revitalizing 'àina (land), restoring kānaka (people) to 'àina, and reconnecting 'ike (knowledge) to place. They should depart with a strong sense of place, skills to plant their own food, and the curiosity and drive to understand how cultivating land and people can maximize the potential of both to sustain life.

Surveys of visitors before and immediately after their visits found that access to Puanui for education and restoration activities fostered cultural reconnection and well-being and encouraged exchanges between community members and resident or visiting scientists. The field system itself and the activities of Ulu Mau Puanui have been covered in local media, and more local people are aware of the LKFS, dryland agricultural systems, and the fact that their ancestors were brilliant farmers, cultivators, land and resource managers, producers, and leaders who valued innovation.

Over time, we have learned that for most of the year, a focus on kupuna (elders) and families in local communities is more productive (in terms of both knowledge and deep and sustained engagement) than is focusing on schools. Schools are constrained in their ability to carry out activities away from campus, particularly in Puanui's relatively remote location, whereas families who are invested in Puanui tend to bring multiple generations to the land repeatedly. Elders frequently bring traditional knowledge of Hawaiian agriculture and transmit it both to us and to younger generations during their visits. In the summer, when local schools are not in session, programs involving school-age learners have been highly rewarding in that students can make multiple visits, conduct their own experiments and measurements, and learn that the use of math and science in a land-based, cultural context is relevant and meaningful.

\section{SCIENTIFIC, LOCAL, AND TRADITIONAL KNOWLEDGE}

Initial investigations into the LKFS that encompasses Puanui were largely scientific, and science continues to be a core activity. For $>30$ years, scientific investigation of the LKFS has been highly interdisciplinary and has woven narratives of human biocomplexity with archaeological, anthropological, biogeochemical, paleobotanical, mathematical, agronomic, and other approaches (Vitousek et al. 2004, Ladefoged et al. 2009, Field et al. 2011a). The studies have contributed to the development of a strong group of indigenous scholars and (we believe) have formed a positive groundwork for incorporating other perspectives and epistemologies encompassed by local and traditional knowledge (Louis 2007, Tipa et al. 2009).

Traditional knowledge is generally considered a complex, holistic, knowledge-practice-belief system that is situated within a socialecological context (Berkes et al. 2000) and that relates to the environment at multiple scales. The biophysical challenges outlined here highlight the varying applicability of traditional knowledge in a changing environmental context. We found traditional knowledge related to dominant landscape features to be highly relevant, i.e., the establishment of rows of sugarcane plays a critical role in making the landscape farmable. In contrast, changes in weather and climate patterns can make the knowledge that informed the location of the plots become out of context, at least temporarily. Finally, entirely new situations such as introduced diseases and pests have arisen for which traditional knowledge was never developed.

Local knowledge often contains traditional knowledge or its remnants, and local knowledge has been important in informing efforts at Puanui. Initial concepts of wind breaks and mist traps, planting methods and spacing, and other details of agricultural 
practices that had been fragmented or lost from traditional knowledge were derived from community input. People with contemporary experience in farming within the region provided essential ideas, knowledge, and resources that allowed for successful plantings. For example, the variety of sweet potato grown, 'Lanikeha,' came from the community. Similarly, different ways of managing the sugarcane rows and different methods for planting sweet potato were suggested and tested by community members.

Bringing science together with local and traditional ecological knowledge is an ongoing process, in part because both evolve with increasing knowledge, changing conditions, and their interaction. The greatest successes occur when it is possible to use local, traditional, and scientific knowledge together, e.g., the establishment of sugarcane rows came from traditional knowledge, the management styles for those rows were informed by local knowledge, and the effectiveness of those management methods was evaluated and refined using scientific experimentation. While efforts are still growing, engagement with different forms of knowledge has been an important cornerstone for reviving these ancient systems and for broadening engagement and interest in the efforts. This is highlighted by the fact that five of the seven coauthors of this paper are indigenous Pacific Islanders.

Responses to this article can be read online at: http://www.ecologyandsociety.org/issues/responses. $\mathrm{php} / 9170$

\section{Acknowledgments:}

This research was supported financially by National Science Foundation grant CNH-0707593 to Stanford University and by support from Kamehameha Schools to Ulu Mau Puanui. We thank Kamehameha Schools and Parker Ranch (landowner and lessee of Puanui, respectively) for their facilitation of this work, as well as Ponoholo Ranch and Parker Ranch for use of their unpublished information on rainfall.

\section{LITERATURE CITED}

Ames, T., N. E. J. M. Smit, A. R. Braun, J. N. O’Sullivan, and L. G. Skoglund. 1997. Sweetpotato: major pests, diseases, and nutritional disorders. International Potato Center, Lima, Peru. [online] URL: http://www.sweetpotatoknowledge.org/wp-content/ uploads/2016/02/SP-ames-et-al.pdf

Armitage, D., M. Marschke, and R. Plummer. 2008. Adaptive comanagement and the paradox of learning. Global Environmental Change 18(1):86-98. http://dx.doi.org/10.1016/j.gloenvcha.2007.07.002

Berkes, F., J. Colding, and K. Folke. 2000. Rediscovery of traditional ecological knowledge as adaptive management. Ecological Applications 10(5):1251-1262. http://dx.doi. org/10.1890/1051-0761(2000)010[1251:roteka]2.0.co;2

Chadwick, O. A., R. T. Gavenda, E. F. Kelly, K. Ziegler, C. G. Olson, W. C. Elliott, and D. M. Hendricks. 2003. The impact of climate on the biogeochemical functioning of volcanic soils.
Chemical Geology 202(3-4):195-223. http://dx.doi.org/10.1016/j. chemgeo.2002.09.001

Chadwick, O. A., E. F. Kelly, S. C. Hotchkiss, and P. M. Vitousek. 2007. Precontact vegetation and soil nutrient status in the shadow of Kohala Volcano, Hawaii. Geomorphology 89(1-2):70-83. http:// dx.doi.org/10.1016/j.geomorph.2006.07.023

Diver, S. W., and M. N. Higgins. 2014. Giving back through collaborative research: towards a practice of dynamic reciprocity. Journal of Research Practice 10(2):M9. [online] URL: http://jrp. icaap.org/index.php/jrp/article/view/415

Durie, M. 2005. Indigenous knowledge within a global knowledge system. Higher Education Policy 18(3):301-312. http://dx.doi. org/10.1057/palgrave.hep.8300092

Dye, T., and E. Komori. 1992. A pre-censal population history of Hawai'i. New Zealand Journal of Archaeology 14:113-128. [online] URL: https://nzarchaeology.org/download/pre-censal-populationhistory-of-hawaii

Field, J. S., T. N. Ladefoged, and P. V. Kirch. 2011a. Household expansion linked to agricultural intensification during emergence of Hawaiian archaic states. Proceedings of the National Academy of Sciences 108(18):7327-7332. http://dx.doi.org/10.1073/ pnas. 1103805108

Field, J. S., T. N. Ladefoged, W. D. Sharp, and P. V. Kirch. $2011 b$. Residential chronology, household subsistence, and the emergence of socioeconomic territories in leeward Kohala, Hawai'i Island. Radiocarbon 53(4):605-627.

Frazier, A. G., and T. W. Giambelluca. 2017. Spatial trends analysis of Hawaiian rainfall from 1920 to 2012. International Journal of Climatology 37(5):2522-2531. http://dx.doi.org/10.1002/ joc. 4862

Fullaway, D. T. 1911. Insects attacking the sweet potato in Hawaii. Hawaii Agricultural Experiment Station Bulletin 22. Paradise of the Pacific Press, Honolulu, Hawaii, USA. [online] URL: https:// www.ctahr.hawaii.edu/oc/freepubs/pdf/B-22.pdf

Giambelluca, T. W., Q. Chen, A. G. Frazier, J. P. Price, Y.-L. Chen, P.-S. Chu, J. K. Eischeid, and D. M. Delparte. 2013. Online rainfall atlas of Hawai'i. Bulletin of the American Meteorological Society 94:313-316. http://dx.doi.org/10.1175/BAMS-D-11-00228.1

Giambelluca, T. W., M. A. Nullet, and T. A. Schroeder. 1986. Rainfall atlas of Hawaii. Report R76. Department of Land and Natural Resources, Honolulu, Hawaii, USA. [online] URL: http://files.hawaii.gov/dlnr/cwrm/publishedreports/R76 Rainfall. pdf

Handy, E. S. C. 1940. The Hawaiian planter, volume I: his plants, methods, and areas of cultivation. Bernice P. Bishop Museum Bulletin 161. Bishop Museum Press, Honolulu, Hawaii, USA.

Handy, E. S. C., and E. G. Handy. 1972. Native planters in old Hawaii: their life, lore, and environment. Bernice P. Bishop Museum Bulletin 233. Bishop Museum Press, Honolulu, Hawaii, USA.

Higgs, E., D. A. Falk, A. Guerrini, M. Hall, J. Harris, R. J. Hobbs, S. T. Jackson, J. M. Rhemtulla, and W. Throop. 2014. The changing role of history in restoration ecology. Frontiers in 
Ecology and the Environment 12(9):499-506. http://dx.doi. org/10.1890/110267

James, H. 1857. No Ka Mahiai. Ka Hae Hawaii, Honolulu, Hawaii, USA.

Kagawa, A. K., and P. M. Vitousek. 2012. The ahupua'a of Puanui: a resource for understanding Hawaiian rain-fed agriculture. Pacific Science 66(2):161-172. http://dx.doi. org/10.2984/66.2.6

Kamakau, S. M. 1976. The works of the people of old. Bishop Museum Proceedings Volume 61. Bishop Museum Press, Honolulu, Hawaii, USA.

Kelly, M. 1983. Nâ mala o Kona, the gardens of Kona: a history of land use in Kona, Hawai'i. Bernice P. Bishop Museum, Honolulu, Hawaii, USA.

Kelly, M. 1989. Dynamics of production intensification in precontact Hawaii. Pages 82-106 in S. Van der Leeuw and R. Torrence, editors. What's new? A closer look at the process of innovation. Unwin Hyman, London, UK.

Kepelino, 1932. Kepelino's traditions of Hawaii. Bernice P. Bishop Museum Bulletin 95. Bishop Museum Press, Honolulu, Hawaii, USA.

Kirch, P. V. 1994. The wet and the dry: irrigation and agricultural intensification in Polynesia. University of Chicago Press, Chicago, Illinois, USA.

Kirch, P. V. 2007. "Like shoals of fish": archaeology and population in pre-contact Hawai'i. Pages 52-69 in P. V. Kirch and J.-L. Rallu, editors. The growth and collapse of Pacific Island societies: archaeological and demographic perspectives. University of Hawaii Press, Honolulu, Hawaii, USA.

Kirch, P. V. 2010. How chiefs became kings: divine kingship and the rise of archaic states in ancient Hawai'i. University of California Press, Berkeley, California, USA.

Ladefoged, T. N., P. V. Kirch, S. M. Gon III, O. A. Chadwick, A. S. Hartshorn, and P. M. Vitousek. 2009. Opportunities and constraints for intensive agriculture in the Hawaiian archipelago prior to European contact. Journal of Archaeological Science 36 (10):2374-2383. http://dx.doi.org/10.1016/j.jas.2009.06.030

Ladefoged, T. N., M. D. McCoy, G. P. Asner, P. V. Kirch, C. O. Puleston, O. A. Chadwick, and P. M. Vitousek. 2011. Agricultural potential and actualized development in Hawai'i: an airborne LiDAR survey of the leeward Kohala field system (Hawai'i Island). Journal of Archaeological Science 38(12):3605-3619. http://dx.doi.org/10.1016/j.jas.2011.08.031

Lincoln, N. K., and P. M. Vitousek. 2016. Nitrogen fixation during decomposition of sugarcane (Saccharum officinarum) is an important contribution to nutrient supply in traditional dryland agricultural systems of Hawai'i. International Journal of Agricultural Sustainability 14(2):214-230. http://dx.doi. org/10.1080/14735903.2015.1071547

Lincoln, N., O. Chadwick, and P. Vitousek. 2014. Indicators of soil fertility and opportunities for precontact agriculture in Kona, Hawai'i. Ecosphere 5(4):art42. http://dx.doi.org/10.1890/ES13-00328.1
Louis, R. P. 2007. Can you hear us now? Voices from the margin: using indigenous methodologies in geographic research. Geographical Research 45(2):130-139. http://dx.doi.org/10.1111/ j.1745-5871.2007.00443.x

Mooney, H. A., and J. A. Drake, editors. 1986. Ecology of biological invasions of North America and Hawaii. Springer, New York, New York, USA. http://dx.doi.org/10.1007/978-1-4612-4988-7

Ostrom, E. 2009. A general framework for analyzing sustainability of social-ecological systems. Science 325 (5939):419-422. http://dx. doi.org/10.1126/science.1172133

Pukui, M. K. 1983. 'Olelo No'eau: Hawaiian proverbs and poetical sayings. Bishop Museum Press, Honolulu, Hawaii, USA.

Stannard, D. E. 1989. Before the horror: the population of Hawai' $i$ on the eve of Western contact. University of Hawaii Press, Honolulu, Hawaii, USA.

Timm, O., and H. F. Diaz. 2009. Synoptic-statistical approach to regional downscaling of IPCC twenty-first-century climate projections: seasonal rainfall over the Hawaiian Islands. Journal of Climate 22:4261-4280. http://dx.doi.org/10.1175/2009JCLI2833.1

Tipa, G., R. Panelli, and Moeraki Stream Team. 2009. Beyond 'someone else's agenda': an example of indigenous/academic research collaboration. New Zealand Geographer 65(2):95-106. http://dx.doi.org/10.1111/j.1745-7939.2009.01152.x

Valenzuela, H., S. Fukuda, and A. Arakaki. 1994. Sweetpotato production guides for Hawai'i. Research Extension Series 146. Hawaii Institute of Tropical Agriculture and Human Resources, University of Hawai'i at Manoa, Honolulu, Hawaii, USA. [online] URL: http://www.extento.hawaii.edu/kbase/reports/ sweetpot prod.htm

Vitousek, P. M., and O. A. Chadwick. 2013. Pedogenic thresholds and soil process domains in basalt-derived soils. Ecosystems 16 (8):1379-1395. http://dx.doi.org/10.1007/s10021-013-9690-z

Vitousek, P. M., O. A. Chadwick, S. C. Hotchkiss, T. N. Ladefoged, and C. M. Stevenson. 2014. Farming the rock: a biogeochemical perspective on intensive agriculture in Polynesia. Journal of Polynesian Archaeology 5(2):51-61.

Vitousek, P. M., C. M. D’Antonio, L. L. Loope, M. Rejmanek, and R. Westbrooks. 1997. Introduced species: a significant component of human-caused global change. New Zealand Journal of Ecology 21(1):1-16. [online] URL: http:// newzealandecology.org/nzje/2008

Vitousek, P. M., T. L. Ladefoged, P. V. Kirch, A. S. Hartshorn, M. W. Graves, S. C. Hotchkiss, S. Tuljapurkar, and O. A. Chadwick. 2004. Soils, agriculture, and society in precontact Hawai'i. Science 304(5677):1665-1669. http://dx.doi.org/10.1126/ $\underline{\text { science. } 1099619}$

Walker, B., C. S. Holling, S. R. Carpenter, and A. Kinzig. 2004. Resilience, adaptability, and transformability in social-ecological systems. Ecology and Society 9(2):5. http://dx.doi.org/10.5751/ es-00650-090205 